\title{
Short wave and net radiation under glass as compared with radiation in the open
}

\author{
D. W. SCHOLTE UBING \\ Laboratory of Physics and Meteorology, Agricultural University, \\ Wageningen, Netherlands
}

\section{Summary}

Measurements of short and long wave radiation were carried out in the open and under a glass roof. The results, given in this paper after a short theoretical discussion of radiation under glass, show a considerable decrease in the flux densities of short wave, net short wave and also net radiation under glass over 24 hrs. as compared with the similar radiant flux densities in the open. The net long wave (back) radiation under glass was fairly constant and low, even under clear skies, as compared with the net back radiation in the open. The nocturnal net radiation under glass was "higher" than it was in the open. However, during the daytime and also over 24 hrs. the net radiation under glass still was always lower than it was in the open. The net radiation under glass did not differ much from the net short wave radiation under glass.

\section{Introduction}

In studies on evapotranspiration from grass (ScHOLTE UBING, 1959) periods of dry "weather" for a trial field ${ }^{1}$ were obtained by screening the field against rain with a glass roof (gabled roof).

The vertical projection of the glass roof was a rectangle of $6.5 \mathrm{~m} \times 5.5 \mathrm{~m}$. The roof consisted of glass $(85 \%)$ and of iron frame work $(15 \%)$. Large window panes were used $(72 \mathrm{~cm} \times 140 \mathrm{~cm}$ ). The thickness of the glass (window glass) was about $3.5 \mathrm{~mm}$. The angles between glass roof and soil surface were $23.5^{\circ}$. The iron roof beam was at a height of $160 \mathrm{~cm}$ above the grass surface, while the smallest distance from the glass roof to the grass surface was about $25 \mathrm{~cm}$. The direction of the longitudinal axis of this "glass-house" was NNE-SSW.

Measurements of the short wave radiation from sun and sky $(0.3 \mu \leqslant \lambda \leqslant 3 \mu)$ in the open, $\boldsymbol{H}_{s h}$, and under the glass roof, ${ }_{g l} \boldsymbol{H}_{s b}$, were carried out both at the same time by means of two Kipp-solarimeters. For a description of the Kipp-solarimeter, its construction and its use reference is made to BENER (1951), REESINCK (1940) and DE VRIES (1955). The influence of the shadows of the frame work was always taken into account in determining the total amount of short wave radiation under glass from the recordings of the Cambridge thread-recorders (REESINCK, 1940).

The net radiation in the open, $H^{\text {net }}$, and under the glass roof, ${ }_{g l} H^{\text {net }}$, was measured by means of two "economical net radiometers", as developed by Suomi and Kuhn in

1 The grass field was located on the meteorological observation field of the Laboratory of Physics and Meteorology at Wageningen, The Netherlands $\left(51^{\circ} 58^{\prime} \mathrm{N}, 5^{\circ} 39^{\prime} \mathrm{E}\right)$.

Received for publication 6th April, 1961. 
the U.S.A. ${ }^{1}$. This kind of net radiometer was only used after a critical valuation of its sensitivity and usefulness. This study and the derivation of more accurate working formulas for these instruments has been given already in a previous paper (SCHOLTE. UbING, 1959). Continuous records of the temperatures of the blackened upper and bottom surfaces of both radiometers were obtained by means of copper-constantan thermo-couples and a Honeywell-Brown recording potentiometer. Owing to the height of the "glasshouse" the net radiometer inside was placed at a height of about $80 \mathrm{~cm}$ above the grass surface. In order to obtain comparable results, the net radiometer in the open was also placed at this height. In fact, $80 \mathrm{~cm}$ is somewhat low for these instruments. However, errors introduced in this way will be small anyhow.

\section{Radiation under a glass roof}

The transmission of common window glass for radiation of wave length $\lambda>3.5 \mu$ is zero (Trickett and Goulden, 1958 ; Forsythe, 1954). According to the data of TRICKETT and GOULDEN the transmission of common window glass for radiation of wave length $\lambda \approx 0.6 \mu$ is about 90 to $100 \%$ (perpendicular irradiation). The data of SeEman (1953) are in close agreement with those of first mentioned authors.

Writing $\gamma_{g t}$ for the mean diurnal transmission coefficient of the glass roof (including the frame work) for short wave solar radiation, and writing for the total irradiation on one $\mathrm{cm}^{2}$ soil surface under glass $H \downarrow$ and for the upward radiation from one $\mathrm{cm}^{2}$ soil surface under glass $H \uparrow$, then,

$$
H \downarrow=H_{s b} \lambda_{g l}+{ }_{g l} H_{l a}^{g l}+(\text { reflected } H \uparrow) \mathrm{cal} \mathrm{cm}^{-2} 24 \mathrm{hrs}^{-1}
$$

and :

$$
H \uparrow={ }_{g l} H_{l o}^{e a}+(\text { reflected } H \downarrow) \mathrm{cal} \mathrm{cm}^{-2} 24 \mathrm{hrs}^{-1},
$$

in which ${ }_{g^{l}} H_{l o}^{g l}=$ long wave radiation from the glass roof under the glass, and ${ }_{g l} H_{l o}^{e a}=$ $=$ long wave radiation from the soil surface under glass.

After substitution of (1) in (2) and (2) in (1), one obtains the net radiation under glass, ${ }_{g l} H^{n e t}$, from $(H \downarrow-H \uparrow)$. With a minor approximation (neglection of higher order products of the reflection coefficients),

$$
\begin{aligned}
{ }_{g l} H^{n e t}=H_{s h} \gamma_{g l}\left(1+r_{s h} r_{g l}^{\prime}-\right. & \left.r_{s h}\right)+{ }_{g l} H_{l o}^{g l}\left(1+r_{l o} r_{g l}^{\prime \prime}-r_{l o}\right)- \\
& -{ }_{g l} H_{l o}^{e a}\left(1+r_{l o} r_{g l}^{\prime \prime}-r_{g l}^{\prime \prime}\right) \mathrm{cal} \mathrm{cm}^{-2} 24 \mathrm{hrs}^{-1},
\end{aligned}
$$

in which $r_{s h}$ and $r_{l o}$ are the average reflection coefficients of the soil surface for short and long wave radiation, respectively, and $r_{g l}^{\prime}$ and $r_{g l}^{\prime \prime}$ the average reflection coefficients of the glass roof for short and long wave radiation, respectively.

In eq. (3), $H_{s b} \gamma_{g l}\left(I+r_{s b} r_{g l}^{\prime}-r_{s b}\right)$ is the net short wave radiation under glass, ${ }_{g l} \boldsymbol{H}_{s b}^{n e t}$. We may write for the short wave radiation under glass :

$$
{ }_{g l} H_{s b}=H_{s b} \gamma_{g l}\left(1+r_{s h} r_{g l}^{\prime}\right) \mathrm{cal} \mathrm{cm}^{-2} \mathrm{day}^{-1},
$$

or :

$$
{ }_{g^{l}} H_{s b}=H_{s b} \gamma_{g^{\prime}}\left[1+\left(1-\gamma_{g^{l}}^{\prime}-a_{g l}^{\prime}\right) r_{s b}\right] \mathrm{cal} \mathrm{cm}^{-2} \mathrm{day}^{-1}
$$

1 Agmet Products Co., Middleton, Wisconsin, U.S.A. 
$\gamma_{\gamma^{\prime}}^{\prime}$ and $a_{g l}^{\prime}$ in eq. (5) are, respectively, the mean transmission and absorption coetficients of the glass roof for the short wave radiation reflected to the glass roof by the soil surface.

Neglecting in eq. (5) the absorption of radiation by the frame work (frame work only $15 \%$ of the total roof surface) and assuming $\gamma_{g^{l}}^{\prime}=\gamma_{g^{l}}$ and $r_{s h}=0.20$ for short grass, then :

$$
{ }_{g l} H_{s b} / H_{s b}=1.2 \gamma_{g^{l}}-0.2\left(\gamma_{g l}\right)^{2} \text {. }
$$

With eq. (4) one finds for the net short wave radiation under glass :

$$
{ }_{g l} H_{s b}^{n e t}={ }_{g_{l} l} H_{s b}-H_{s b} \gamma_{g^{l}} r_{s h} \quad \mathrm{cal} \mathrm{cm}^{-2} \mathrm{day}^{-1} \text {. }
$$

After substitution of eq. (6) in eq. (7) one obtains the ratio:

$$
{ }_{g l} H_{s h}^{m e t} /_{H_{s h}}=\gamma_{g l}-0.2\left(\gamma_{g l}\right)^{2} .
$$

\section{Experimental results}

The nocturnal net radiation (net long wave back radiation from the soil surface) measured under the glass roof and, at the same time, in the open during some nights with clear, overcast and broken skies, is given in the FIGURE. Under glass, the nocturnal net long wave back radiation was always very low, about 0.005 to $0.015 \mathrm{cal} \mathrm{cm}^{-2}$

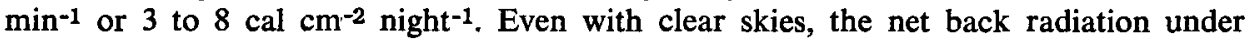
glass dit not differ much from the net back radiation under a heavy cloud cover. One could conclude that with a glass roof ${ }_{g l} H_{l o}^{g l} \approx{ }_{g l} H_{l_{o}}^{e a}$ and that at night, therefore, the temperature of the glass roof did not differ very much from the temperature of the effective radiant grass surface under glass. The net back radiation during the daytime can be computed from eq. (3) if ${ }_{g l} H_{s / l}^{\text {net }}$ is known.

$\gamma_{g^{l}}$ varies with solar altitude and the ratio of eq. (6), therefore, shows a diurnal and an annual variation (In this paper, however, the diurnal variation does not come up for discussion since $\gamma_{g l}$ here is an average daily value). On $7 / 1 /, 58,8 / 1 /, 58,9 / 1 /$ '58 and $9 / 15 / ' 58$ this ratio amounted to, respectively, $0.69,0.67,0.64$ and 0.62 for the kind of glass roof used here. For the period from $8 / 8$ till $8 / 18 / 1958$, during which period the net radiation under glass was measured, the ratio ${ }_{g l} H_{s b} / H_{s b}$ equalled about 0.66 . With eq. (6) one obtains an average transmission coefficient for the glass roof including the frame work for this period of about $61.2 \%$. Comparing this value for $\gamma_{g l}$ with 0,66 , it follows that the incoming short wave radiation under glass had increased with reflected radiation in this "glass-house" amounting to about $4,8 \%$ of $\boldsymbol{H}_{s h}$. So, this numerical example is in accordance with the theory given (see eq. (4)). In the period from 8/8 till 8/18/1958 the net (long wave) back radiation over $24 \mathrm{hrs}$. under glass, under clear skies as well as under cloudy skies, amounted to 20 to $30 \mathrm{cal}$ $\mathrm{cm}^{-2}$, while in the open the net back radiation varied from 20 to $78 \mathrm{cal} \mathrm{cm}^{-2} 24 \mathrm{hrs}^{-1}$. In another paper (SCHOLTE UBING, 1959) author showed that there exists a nearly lineair relation between $H_{s b}$ and the net back radiation in the open and he has proved that this relation is affected mainly by cloudiness. Here, in the case of a glass cover, however, this relation (now between $H_{s b}$ and ${ }_{g} H_{l o}^{\text {nef }}$ ) becomes considerably less pronounced. This is only due to the glass cover itself. ${ }_{g l} H_{l o}^{n f t}$ becomes more or less 
FIGURE. Nocturnal net radiation measured under the glass roof and in the open, under different cloud conditions of the sky. The net radiation determined by means of "economical net radiometers". Observations at Wageningen, Netherlands.

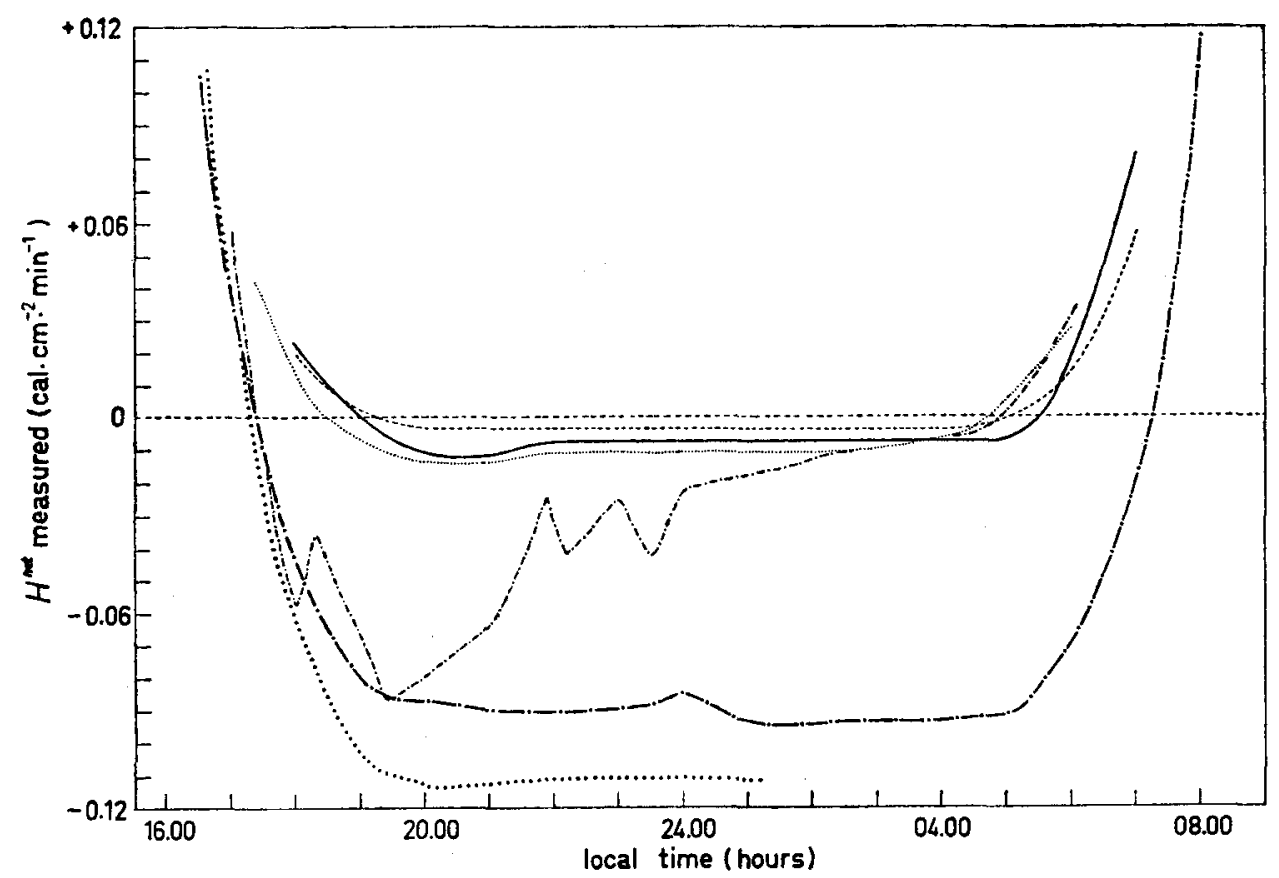

constant. Consequently, the net radiation under glass will not differ much from the net short wave radiation under glass.

For the above mentioned period we found the following regression equations :

$$
{ }_{g l} H^{\text {net }}=0.93_{g l} H_{s h}^{n e t}-14.0 \mathrm{cal} \mathrm{cm-2} 24 \mathrm{hrs}^{-1} \text {, }
$$

and :

$$
{ }_{g l} H^{n e t}=0.75_{g l} H_{s h}-13.5 \mathrm{cal} \mathrm{cm}^{-2} 24 \mathrm{hrs}^{-1} .
$$

The net radiation over $24 \mathrm{hrs}$. under glass was decreased about 25 to $30 \%$ as compared with the net radiation in the open, although the net back radiation under glass was lower than the net back radiation in the open. Thus, the decrease in net short wave radiation (about 30 to $35 \%$ ) was not compensated by a low back radiation. With the correct values for $\gamma_{g^{l}}$ it was possible to estimate reasonably ${ }_{g l} H^{\text {met }}$ for other periods with the help of measured values of ${ }_{g l} H_{s i j}^{\text {net }}$ or ${ }_{g l} H_{s h}$. 
The influence of this glass roof on short and long wave radiation under a clear sky, a broken sky, an overcast and a heavy cloudy sky is given in the TABLE.

TABLE. Radiation under glass compared with radiation in the open air on days with various cloudiness (cal cm-2 $24 \mathrm{hrs}^{-1}$ ). $H_{s h}, H_{s b}^{\text {net }}, H_{l o}^{\text {net }}, H^{\text {net }}=$ short wave radiation from sun and sky, net short wave radiation, net long wave radiation and net radiation respectively. Addition of $g^{\prime}$ to the symbol means: quantity measured under the glass roof. $n / N=$ percentage of actual sunshine.

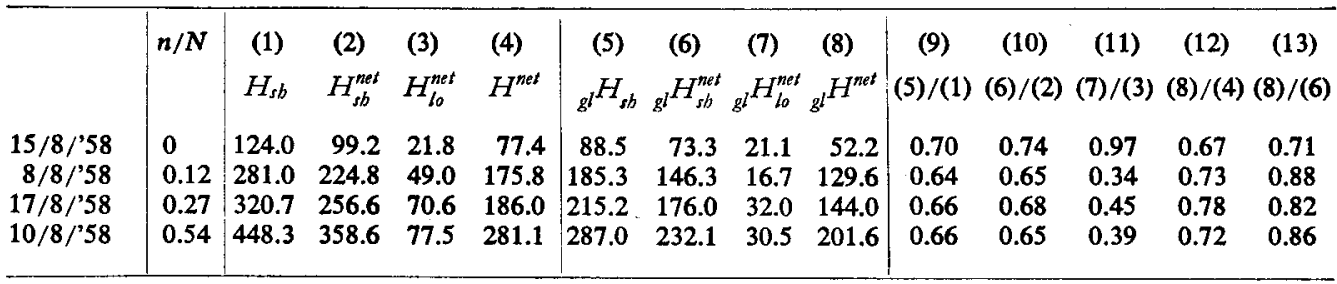

In applying the foregoing theory to other glass houses the differences in construction must be taken into account of course.

\section{T ERAT U RE}

BENER, P.

ForsYTHE, W. E.

REESINCK, J. J. M.

Scholte UbING, D. W.

Seeman, J.

TricketT, E. S., and J. D. S. GouldeN

VRIES, D. A. DE
1951 Untersuchungen über die Wirkungsweise des Solarigraphen Moll-Gorczynski. Archiv f. Meteorologie, Geophysik und Bioklimatologie. B II, p. 188.

1954 Smithsonian Physical Tables. 9th ed. Published by the Smithsonian Institution, Washington D.C.

1940 Het verband tussen zonneschijnduur, bewolking en stralingsintensiteit in Nederland. Meded. Landbouwh.school Wageningen. 44, Verh. 5.

1959 Over stralingsmetingen, de warmtebalans en de verdamping van gras (Studies on solar and net radiation and on evapotranspiration from grass). Meded. Landbouwh.school Wageningen. 59 (10), 1-93.

1953 Strahlungsverhältnisse in Gewächshäusern. Archiv f. Meteorologie, Geophysik und Bioklimatologie. 4, p. 193.

1958 The radiation transmission and heat conserving properties of glass and some plastic films. Journ. Agric. Engin. Research. 3, p. 28.

1955 Solar radiation at Wageningen. Meded. Landbouwh.school Wageningen. 55, p. 277. 